\title{
Recruitment behavior in stingless bees, Melipona scutellaris and M. quadrifasciata. I. Foraging at food sources differing in direction and distance
}

\author{
Stefan JARAU ${ }^{\mathrm{a}}$, Michael HRNCIR ${ }^{\mathrm{a}}$, Ronaldo ZUCCHI ${ }^{\mathrm{b}}$, \\ Friedrich G. BARTH ${ }^{\mathrm{a} *}$ \\ ${ }^{\text {a }}$ Universität Wien, Biozentrum, Institut für Zoologie, \\ Abteilung Physiologie - Neurobiologie, Althanstraße 14, A-1090 Wien, Austria \\ b Universidade de São Paulo, Faculdade de Filosofia e Letras, \\ Departamento de Biologia 14040-901 Ribeirão Preto, SP, Brazil
}

(Received 28 April 1999; revised 6 September 1999; accepted 22 September 1999)

\begin{abstract}
The two stingless bee species Melipona scutellaris and M. quadrifasciata recruit nestmates to a rich foraging site. We tested this with feeders up to $140 \mathrm{~m}$ away from the hive. Foragers of M. scutellaris communicated direction (up to $140 \mathrm{~m}$ ) more accurately than distance (up to $30 \mathrm{~m}$ ) whereas those of $M$. quadrifasciata communicated direction only up to $30 \mathrm{~m}$ and distance up to $40 \mathrm{~m}$. Our data indicate that in both species recruitment is divided into two temporal phases. Whereas in an initial phase alarmed nestmates search for food at random, bees leaving the hive in the following phase are obviously provided with information about its specific location. As a consequence after 35 minutes (M. scutellaris) and 85 minutes (M. quadrifasciata), respectively, significantly more newcomers arrive at the feeder than at an identical control feeder. The differences found in the recruitment success of $M$. scutellaris and $M$. quadrifasciata are discussed in regard to the different demands of their natural habitats.
\end{abstract}

stingless bee / foraging / recruitment / direction and distance communication / Melipona species

\footnotetext{
* Correspondence and reprints

E-mail: friedrich.g.barth@univie.ac.at
} 


\section{INTRODUCTION}

Stingless bees (Meliponinae), like honeybees (Apinae), are eusocial insects. Communication between individuals is imperative for the survival of their colonies and in many species the recruitment of field bees by foragers seems to be as important for the exploitation of rich food sources as it is in honeybees [11].

In Melipona scutellaris, one of the species studied by us, foragers failed to communicate the distance of a food source in the experiments reported by Lindauer and Kerr [11]. In addition the number of newcomers at the feeder was only slightly larger than at a control feeder in an experiment designed to test the ability to communicate direction [11]. Later, Nieh and Roubik [14] found these results not to be statistically significant. It thus remains uncertain whether foragers of $M$. scutellaris are indeed communicating information on the distance and direction of a food source. Similarly, for $M$. quadrifasciata, the other species examined in the present study, it only seems to be clear that direction is communicated more accurately than distance [9]. The significance of acoustic signaling for distance communication is still doubtful and its function remains uncertain $[2,3,5,14]$. The available studies do show, however, that successful foragers of both $M$. scutellaris and M. quadrifasciata cause some nestmates to leave their nest in search of food. Unfortunately, there have been hardly any attempts to further clarify the recruitment behavior of these two species in detail for the last 35 to 40 years [7] nor is recruitment behavior fully understood in any other stingless bee.

Nieh and Roubik [14] and Nieh [13], treating their data statistically, recently demonstrated that foragers of Melipona panamica recruit nestmates to a food source in a specific direction, distance, and even height above ground without using scent marks over long distances.

The present study on M. scutellaris and M. quadrifasciata seeks to answer the fol- lowing questions: (1) Do foragers recruit nestmates to food sources in specific directions and at specific distances from the hive? (2) How efficient is their recruitment? (3) Does recruitment success follow any temporal pattern?

\section{MATERIALS AND METHODS}

\subsection{Study site and colonies}

The experiments were carried out on the Ribeirão Preto Campus of the Universidade de São Paulo, Brazil between September 1996 and February 1997. We used one colony of Melipona scutellaris and one colony of $M$. quadrifasciata. The natural habitat of both species are the regions of the former atlantic rainforest (Mata Atlântica), with M. scutellaris occurring in Northeast Brazil (from Pernambuco to the South of Bahia) and M. quadrifasciata occurring in the southeast (from Minas Gerais to Santa Catarina) (João M. F. de Camargo, unpublished data). Both species nest in tree cavities with 400-600 and 300-400 adult individuals, respectively [11]. Worker size is 10-12 $\mathrm{mm}$ in M. scutellaris and $8-10 \mathrm{~mm}$ in M. quadrifasciata. Our experimental colonies were kept in wooden boxes inside the laboratory with plastic entrance tubes $(15 \mathrm{~mm}$ in diameter) inserted through the wall of the building.

\subsection{Feeding stations}

As feeders we used Schott-Duran laboratory glass dishes (27 mm high, $40 \mathrm{~mm}$ in diameter) placed upside down on hexagonal plexiglass plates (77 $\mathrm{mm}$ in diameter) with six radially arranged grooves allowing the bees to take up the sugar water. The feeders were filled with sugar water $\left(0.75 \mathrm{~mol} \cdot \mathrm{l}^{-1}\right.$ for training, $1.5 \mathrm{~mol} \cdot \mathrm{l}^{-1}$ for experiments) scented with $3 \mu \mathrm{l}$ essence of rosewood (Aniba rosaeodora)/ml solution and rested on stools $90 \mathrm{~cm}$ above ground. 


\subsection{Marking of bees}

On the day before an experiment we marked all bees landing on a feeder right in front of the colony entrance with a unique combination of two out of five different colors [4]. Unmarked bees showing up at a feeder during the experiments were captured and marked at the end of the experiment (see training experiments).

\subsection{Training experiments}

A feeder containing a $0.75 \mathrm{~mol} \cdot \mathrm{l}^{-1}$ sugar solution was placed in front of the hive. With five marked bees collecting regularly at the feeder the food source was moved in steps of a few meters up to its final position. There the foragers were allowed to collect sugar water for another 15 minutes before the feeder was removed. Bees other than the trained foragers at the feeder were caught and kept in a jar until the end of the experiment.

Foragers were always trained between $9 \mathrm{~h}$ and $11 \mathrm{~h}$ in the morning. After a break with no feeder each experiment began at $13 \mathrm{~h}$ and lasted until $16 \mathrm{~h}$. Early afternoon was chosen for the experiments, because in other species of the genus Melipona nectar intake is known to be highest late in the morning and early in the afternoon $[1,17]$, suggesting that the propensity to be recruited is particularly high at these times.

The experimental feeder offering a $1.5 \mathrm{~mol} \cdot \mathrm{l}^{-1}$ sugar solution was installed at the location the five foragers had been trained to in the morning of the same day. $5 \mathrm{ml}$ of the same solution were injected into the entrance tube of the colony's hive. Within a few minutes all five foragers showed up at the feeder. A control feeder was installed at a location which differed from that of the experimental feeder only in either direction to the hive or distance from the hive. The feeders were never positioned in the same direction from the hive on

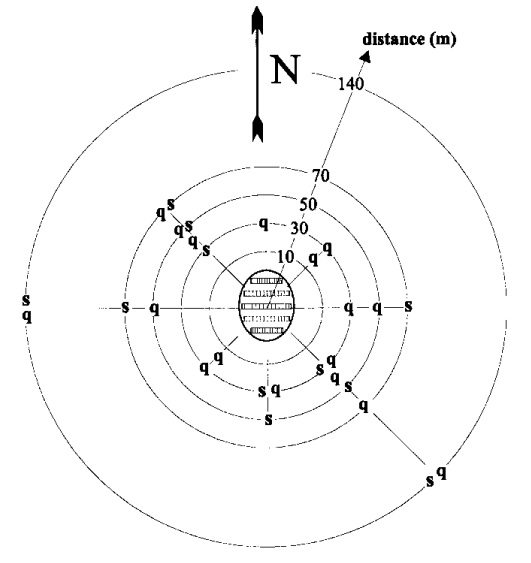

Figure 1. The locations of the experimental feeder relative to the bee colonies (indicated by the nest symbol). The control feeders are not shown. North is indicated by the arrow, the numbers represent distances (m) from the hive. $s$ and $q$, feeding stations in experiments with Melipona scutellaris and Melipona quadrifasciata, respectively.

consecutive days. Figure 1 shows all feeder locations used in the experiments.

The time of every arrival of the five foragers at the feeder was recorded as were number and arrival time of the newcomers at both, feeder and control feeder. All newcomers were caught at the feeders, kept in glass vessels, and provided with sugar water until the end of the experiment.

To test the efficiency of recruitment and whether its success changed during the forager's phase of activity, the data of all training experiments were pooled. An experiment's entire duration (180 minutes) was divided into sections of five minutes. The numbers of newcomers arriving at the feeder or the control feeder, respectively, were summed for each of these 36 intervals to identify a possible temporal recruitment pattern. Since the experiments were carried out in the same area, at the same time of day (13 h to $16 \mathrm{~h}$ ), at similar weather conditions, and using the same bee colonies, errors by pooling data based on different experimental conditions were excluded. 


\subsection{Statistics}

For each training experiment and for the changes in the recruitment success we calculated the $\chi^{2-}$ probability (significance level $p \leq 0.05$ ) of the observed distribution of newcomers at the feeder and at the control feeder.

\section{RESULTS}

\subsection{Production of sounds depending on sugar concentration}

When using a $0.75 \mathrm{~mol} \cdot \mathrm{l}^{-1}$ sugar solution during the training procedure foragers did not produce any signals inside the hive
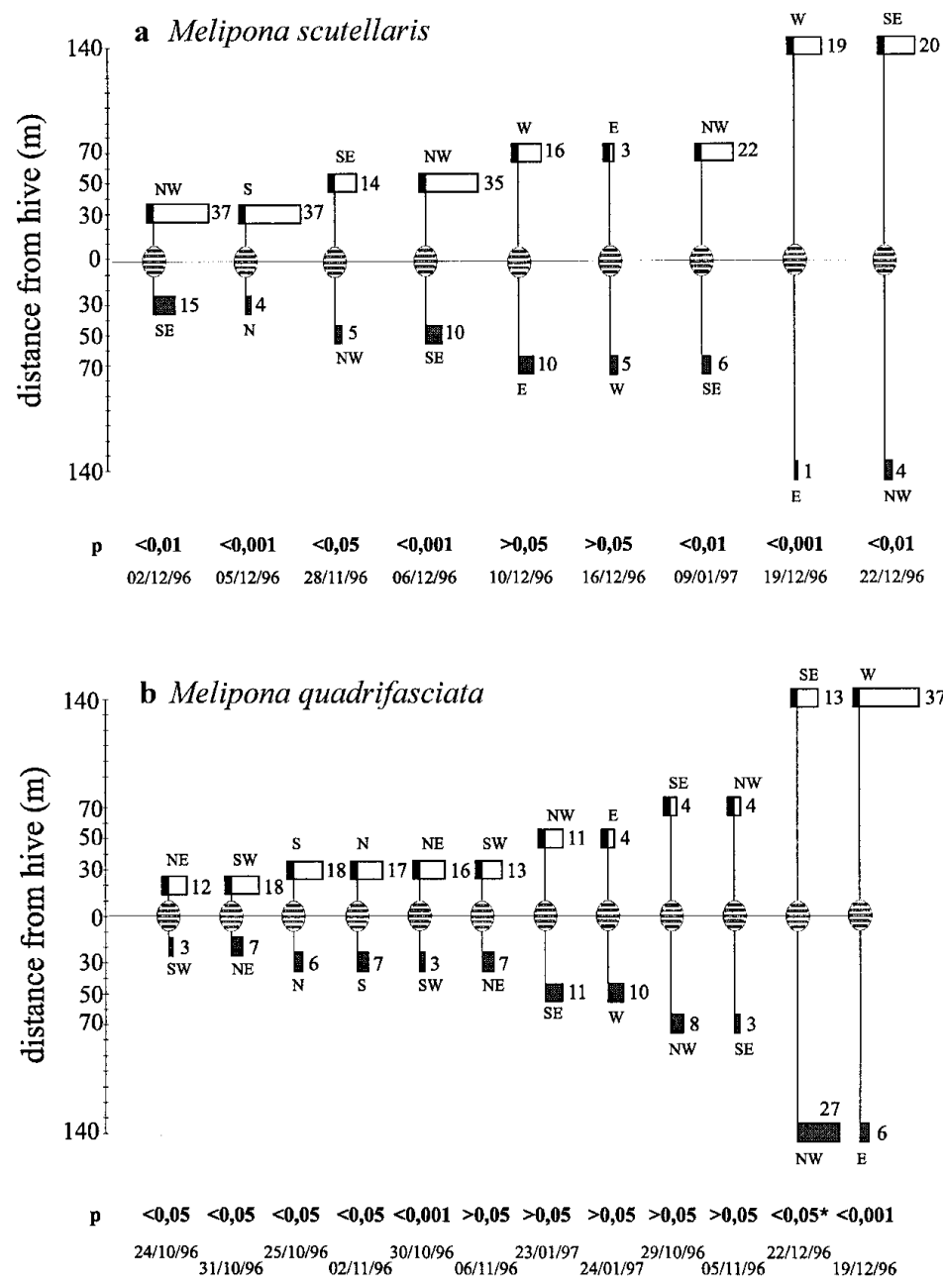

Figure 2. Communication of direction in (a) M. scutellaris and (b) M. quadrifasciata. Black bars, the five foragers of each experiment; white bars, newcomers at the experimental feeder; shaded bars, newcomers at the control feeder; numbers beside bars, bees captured at each feeder. For each experiment the date, the compass directions of the feeding stations relative to the hive $(E, N, N W, W$, $S, S E$ ) and the probability for randomness of the observed distribution of newcomers at the feeder and the control feeder, respectively, are given. The asterisk indicates that significantly more newcomers arrived at the control feeder than at the experimental feeder. 
nor were any newcomers recruited. Sound production, vibrations, and recruitment by foragers only occurred when we offered $1.5 \mathrm{~mol} \cdot \mathrm{l}^{-1}$ sugar solution during the experiment.

\subsection{Recruitment to a food source in a specific direction from the hive}

In seven out of nine experiments with Melipona scutellaris, significantly more newcomers arrived at the feeder than at the control feeder which was located at the same distance from the hive but in the opposite direction (Fig. 2a). The success of the recruitment did not depend on the food source's compass direction relative to the hive nor on its distance $(30,50,70,140 \mathrm{~m})$ from the hive. However, the two experiments with the feeder at $70 \mathrm{~m}$ east and at $70 \mathrm{~m}$ west, respectively, showed no significant difference between the number of newcomers at the feeder and the control feeder.
In M. quadrifasciata (Fig. 2b) only at feeder distances within $30 \mathrm{~m}$ from the hive, with one exception, significantly more newcomers arrived at the feeder than at the control feeder. At a distance of $140 \mathrm{~m}$, in one experiment significantly more newcomers arrived at the feeder but in the other experiment significantly more newcomers reached the control feeder. In the latter experiment the control feeder was close to $(4$ to $7 \mathrm{~m}$ ) two flowering trees. Some bees captured at our feeder carried pollen most likely collected on these trees.

\subsection{Recruitment to a food source in a specific distance from the hive}

In M. scutellaris (Fig. 3a), significantly more newcomers reached the feeder than the control feeder when it was placed at a distance of $30 \mathrm{~m}$ from the hive, no matter whether the control feeder was closer to the
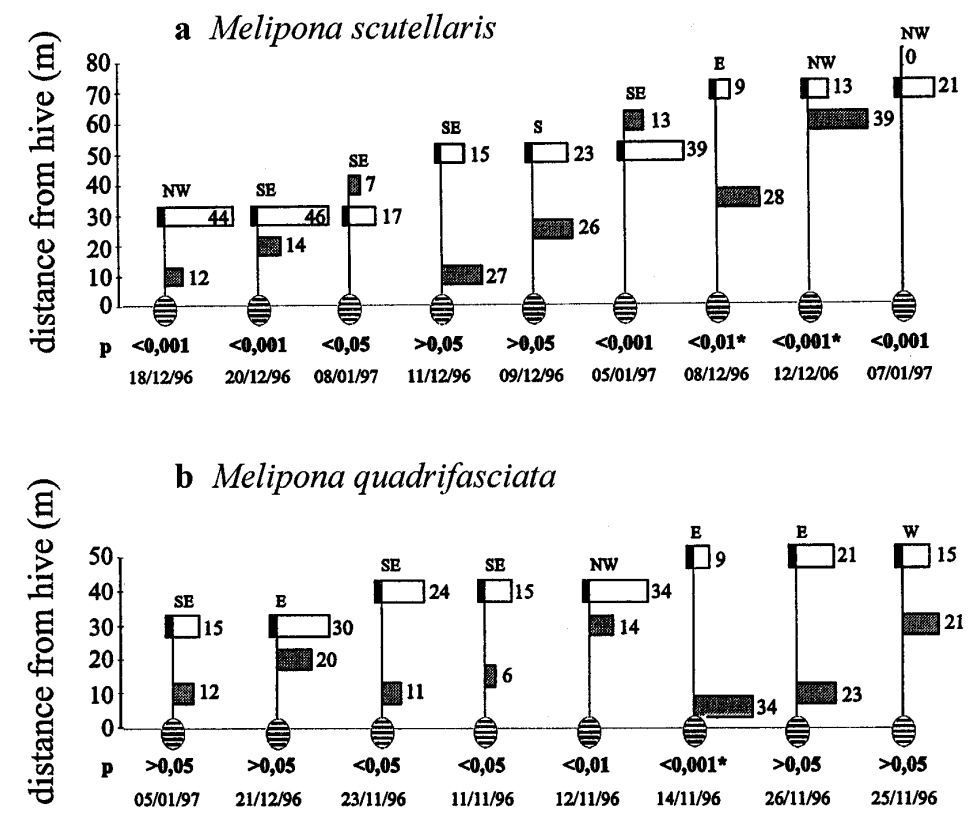

Figure 3. Communication of distance in (a) M. scutellaris and (b) M. quadrifasciata. For further details see Figure 2. 
a Melipona scutellaris

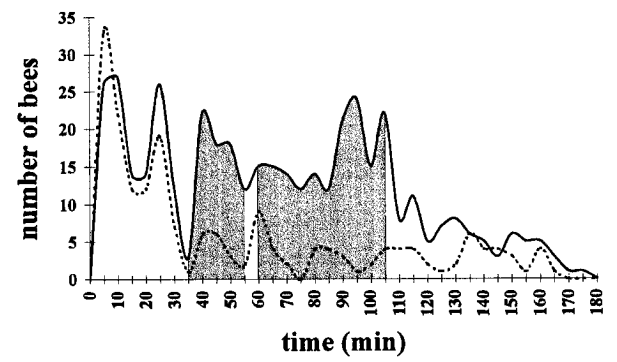

b Melipona quadrifasciata

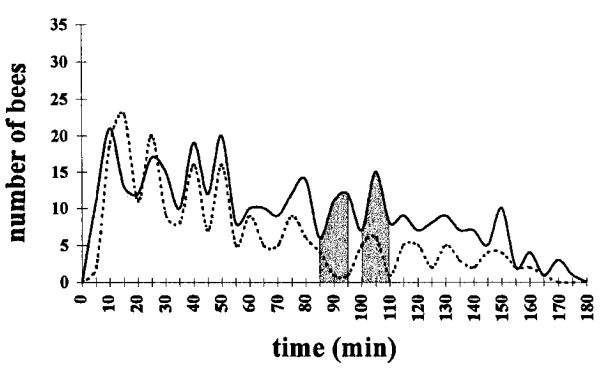

Figure 4. Temporal recruitment pattern in (a) $M$. scutellaris and (b) M. quadrifasciata. The numbers of all bees recorded during the training experiments were summed and blocked for periods of five minutes. Solid line, newcomers at the feeder; dashed line, newcomers at the control feeder. In the shaded sections significantly more newcomers reached the feeder than the control feeder.

hive or further away. With the feeder at $50 \mathrm{~m}$ and $70 \mathrm{~m}$, respectively, we only observed more newcomers at the feeding station when it was closer to the hive than the control feeder.

In M. quadrifasciata (Fig. 3b), significantly more newcomers arrived at the feeder only when it was placed $40 \mathrm{~m}$ away from the hive. In all other cases statistically equal numbers of newcomers were captured at both, the feeder and the control feeder. In one experiment with the feeder at a distance of $50 \mathrm{~m}$ from the hive significantly more newcomers reached the control feeder, which was placed only five meters away from the hive.

\subsection{Recruitment efficiency and temporal recruitment pattern}

In Melipona scutellaris (Fig. 4a), the numbers of newcomers at the feeder and at the control feeder, respectively, were statistically equal during the first 35 minutes of the experiments. After that initial phase significantly more newcomers reached the feeder than the control feeder until the 105th minute, with only one exception between minutes 56 and 60. After 105 minutes the number of bees arriving at both the feeder and the control feeder in general decreased. At this time the limited number of field bees in the colony probably had already been removed at the feeders to a substantial degree. In M. quadrifasciata (Fig. 4b) significantly more newcomers arrived at the feeder only between minutes 85 and 95 and between minutes 100 and 110. During the first 50 minutes of the experiments many bees left the hive, reaching the feeder and the control feeder in almost equal numbers. In M. quadrifasciata, the number of bees captured later than that in general decreased with time.

\section{DISCUSSION}

According to the few studies available, the success of recruiting nestmates and the ability to direct them to the food differs considerably between species of stingless bees. Thus, while foragers of Trigona iridipennis are able to inform their nestmates about the existence of a food source, they do not provide them with any information about its location [10]. Melipona scutellaris, M. quadrifasciata, Trigona droryana and Nannotrigona sp. seem to represent an intermediate group regarding recruitment success, with only a few newcomers reaching the food source [11]. Trained foragers of $T$. silvestris and $T$. jaty hardly recruit any new bee whereas the recruitment success of T. ruficrus, Scaptotrigona sp., Geotrigona sp. and Cephalotrigona sp. is similar to that 
of the honeybee, Apis mellifera. Unfortunately, for the majority of these species the results so far available are based on only one experiment and thus of only limited significance.

\subsection{Direction versus distance communication}

Our study confirms the now classical observations by Lindauer and Kerr [11] and by Kerr et al. [9] by providing evidence that (i) foragers of Melipona scutellaris and M. quadrifasciata indeed do recruit nestmates to a rich foraging site and that (ii) in both species communication of direction is more accurate than communication of distance.

According to our data, M. scutellaris foragers inform their nestmates adequately about the direction to the food source whereas the information on distance - if any - must be very poor. Recruited bees seem to leave the hive in the direction communicated by the forager and to search for a food source smelling like the sample previously taken in the hive. In other species of stingless bees such as Trigona silvestris, T. flavicornis and T. testaceicornis the odor of the food is indeed the most important factor in communication [6]. Possibly the bees first search at approximately $30 \mathrm{~m}$ from the hive which would explain why significantly more newcomers were captured at the feeder than at a control feeder at this distance. With the feeder more than $30 \mathrm{~m}$ away, the bees searching for food first encountered the control feeder with the same smell and food. Correspondingly, significantly fewer bees reached the control feeder when it was further away than the feeder. Future experiments will have to be carried out with unscented food to better understand the role played by the food odor.

M. scutellaris left the hive at a very early stage of the experiment, obviously alarmed by a forager's sound signals produced inside the nest [5]. In this initial phase the bees seem to search for the food source at random, as they reached the feeder and control feeder in statistically equal numbers. It took 35 minutes until significantly more newcomers arrived at the feeder than at the control feeder, suggesting that the bees were then provided with information about the food's location.

According to the present study the recruitment to a specific food location is less accurate in M. quadrifasciata than in M. scutellaris although in this species the recruitment to a specific direction is quite effective up to distances $\leq 30 \mathrm{~m}$. Again, like in M. scutellaris, the communication of distance is not accurate. From the recruitment pattern we concluded that, in M. quadrifasciata, recruited bees do not search for a food source at random, but that there is only poor communication about the location of a feeding site. Only during a short period in our experiments significantly more newcomers reached the feeder than the control feeder.

\subsection{Comparison with Melipona panamica}

Both species of Melipona examined in this study seem to recruit new bees to a food source less precisely than is reported for Melipona panamica [14] if only the significance of the difference of the number of newcomers arriving at the feeder and the control feeder, respectively, is evaluated. However, this may be due to different experimental procedures. Whereas we trained five foragers to a food source Nieh and Roubik [14] trained ten or fifteen foragers. Also, our experiments followed a strict time schedule and lasted for three hours each whereas Nieh and Roubik [14] ended an experiment whenever significantly more bees $(p \leq 0.05)$ had arrived at the experimental than at the control feeder. Data on the duration of their experiments are not given, but some of them lasted for several days. When comparing the absolute numbers of newcomers arriving at the feeder, M. scutellaris (3-46) and 
M. quadrifasciata (4-37) turn out to recruit - or at least to alarm - their nest mates more effectively than $M$. panamica (5-14). In addition the colonies of $M$. panamica contained more adult individuals (500-800) than those of M. scutellaris (400-600) and M. quadrifasciata (300-400).

According to Nieh and Roubik [14] $M$. panamica is even able to communicate the height of a food source above ground level without using a scent trail. Unfortunately, no similar experiments are available for M. scutellaris and M. quadrifasciata. Like in $M$. panamica scentmarking and guiding flights are unimportant in the communication system of the other two Melipona species, at least under certain conditions [5] and in disagreement with earlier observations [7].

\subsection{An ethoecological speculation}

The differences we found between $M$. scutellaris and M. quadrifasciata may reflect differences in their natural habitats. The regions of the Brazilian Atlantic rainforest where $M$. quadrifasciata naturally occurs are covered with dense vegetation, whereas $M$. scutellaris lives in areas with open forest (João M.F. de Camargo, unpublished data). Mass-flowering trees are the most important food plants of the highly eusocial bees in the tropics $[18,19]$. These trees may be more abundant and easier to encounter in a dense forest (habitat of $M$. quadrifasciata) than in an open forest (habitat of M. scutellaris). Thus a more or less random search may be an adequate strategy for $M$. quadrifasciata. In addition the biomass of a colony is said to correlate positively with the absolute foraging distance and the effectiveness of communication [12]. The larger the colony or the greater the flight range, the greater the need for an effective communication. The species investigated here live in colonies of 300-400 and 400-600 adult individuals, respectively.
Information on the flight range of stingless bees is very scarce [15]. Roubik and Aluja [16] determined maximum flight ranges, which need not be equivalent to maximum foraging ranges, for Trigona capitata $(1.5 \mathrm{~km})$ and Melipona fasciata $(2.1 \mathrm{~km})$ by releasing marked bees at various distances from the hive and recording those who found their way home. For M. scutellaris no such data is available whereas $2.0 \mathrm{~km}$ is given for M. quadrifasciata in the literature [8].

\subsection{Temporal pattern}

In both species the temporal recruitment pattern shows an initial phase where bees leave the hive and search for food sources at random before they obviously make use of information about the location of a particular food site. This finding suggests the following sequence of events: (i) when a forager discovers a rich food source, she first communicates its existence, smell, and quality inside the hive. (ii) Alarmed nestmates fly out looking for an equal food source at random. This may be a successful strategy in habitats with mass-flowering plants, as it occurs in tropical forests. (iii) Those bees that have not found a food source by random search after a certain period of time then leave the hive with information about the location of a food site, or at least about its direction from the hive.

\section{ACKNOWLEDGEMENTS}

We are very grateful to Warwick E. Kerr, who kindly provided a colony of Melipona scutellaris from his private meliponary in Uberlândia - Minas Gerais and shared his long experience with stingless bees with us. We also thank Sidney Mateus for his unfailing help in handling the bees. This work was partly supported by a grant from the BMFWK of Austria to SJ and $\mathrm{MH}$ and by money made available to FGB by the Convenio between the University of São Paulo and the University of Vienna. 
Résumé - Comportement de recrutement des abeilles sans aiguillon, Melipona scutellaris et Melipona quadrifasciata. I. Butinage à des sources de nourriture situées dans des directions et à des distances variables. Cherchant principalement à étudier les mécanismes sensoriels impliqués dans le comportement de recrutement des abeilles sans aiguillon (voir l' article associé [5]), nous avons d'abord voulu établir de façon certaine si les deux espèces étudiées Melipona scutellaris et Melipona quadrifasciata recrutaient ou non des butineuses pour une source de nourriture donnée. Pour chaque expérience nous avons dressé cinq butineuses marquées à venir visiter un nourrisseur distant de $140 \mathrm{~m}$ au maximum de la ruche (Fig. 1). Durant trois heures nous avons prélevé toutes les nouvelles venues sur le nourrisseur test et sur le nourrisseur témoin, qui différait l'un de l'autre soit par la distance, soit par la direction. A l'aide du test $\chi^{2}$ (niveau de signification $p \leq 0,05$ ) nous avons testé la répartition des abeilles sur les deux nourrisseurs par rapport au hasard.

Les deux espèces recrutent bien des congénères du nid pour une source de nourriture bien approvisionnée. Chez $M$. scutellaris la direction (jusqu'à 140 m, Fig. 2a) est communiquée plus précisément que la distance (jusqu'à 30 m, Fig. 3a), alors que chez M. quadrifasciata la direction n'est communiquée que jusqu'à $30 \mathrm{~m}$ (Fig. 2b) et la distance jusqu'à $40 \mathrm{~m}$ (Fig. 3b). Chez les deux espèces le recrutement comporte deux phases : dans la phase initiale les congénères mises en alerte cherchent la nourriture au hasard ; dans la seconde phase, les abeilles qui quittent la ruche possèdent visiblement l'information sur la localisation spécifique de la nourriture. En conséquence, au bout de 35 min pour $M$. scutellaris et 85 min pour M. quadrifasciata, les nouvelles venues arrivent en plus grand nombre sur le nourrisseur test (Fig. 4). Ce résultat suggère la succession suivante d'événements : 1) quand une butineuse découvre une source de nourriture bien approvisionnée, elle communique d'abord son existence, son odeur et sa qualité à l'intérieur de la ruche ; 2) les congénères alertées sortent et cherchent au hasard une source de nourriture équivalente. Ceci peut constituer une stratégie fructueuse dans des habitats, tels que la forêt tropicale, où les plantes fleurissent en masse ; 3 ) les abeilles, dont la recherche au hasard a été infructueuse retournent à la ruche, et obtiennent, des butineuses, qui rentrent chargées, l'information sur la localisation de la source.

Les différences entre les deux espèces peuvent peut-être s'expliquer par la différence de leurs milieux naturels : $M$. quadrifasciata vit dans la végétation dense de la forêt pluviale atlantique du Brésil, où les arbres de floraison massive peuvent être plus abondants ou plus faciles à rencontrer que dans une forêt ouverte, qui est l'habitat de M. scutellaris. Une recherche faite plus ou moins au hasard peut suffire à $M$. quadrifasciata.

Melipona abeille sans aiguillon / butinage / recrutement / communication animale / direction et distance

Zusammenfassung - Rekrutierungsverhalten bei stachellosen Bienen (Melipona scutellaris und Melipona quadrifasciata). I. Sammeln an Futterquellen in unterschiedlicher Richtung und Entfernung. In der Absicht, sensorische Mechanismen des Rekrutierungsverhaltens stachelloser Bienen zu analysieren (siehe Begleitartikel, [5]), mußte zunächst zweifelsfrei festgestellt werden, ob die beiden untersuchten Arten, Melipona scutellaris und M. quadrifasiata, Sammelbienen zu einer bestimmten Futterstelle rekrutieren oder nicht. Für alle Experimente wurden fünf markierte Sammlerinnen zu einem Futterplatz trainiert (max. Entfernung 140 m, Abb. 1). Drei Stunden lang wurden alle Neuankömmlinge an der Futterquelle und einer Kontrollfutterquelle, die sich nur bezüglich der Richtung vom oder der Entfernung zum Stock 
von der Futterquelle unterschied, gesammelt. Mit Hilfe des $\chi^{2}-$ Tests (Signifikanzniveau: $p \leq 0.05$ ) wurde die Verteilung der Bienen an den beiden Futterstellen auf ihre Zufälligkeit überprüft.

Sammelbienen beider Arten können ihre Stockgenossinen zu einer lohnenden Futterstelle rekrutieren. Bei M. scutellaris wird die Richtung einer Futterquelle bis zu einer Entfernung von $140 \mathrm{~m}$ (Abb. 2a) von den Sammlerinnen genauer übermittelt als deren Entfernung (bis zu 30 m, Abb. 3a). Bei M. quadrifasciata hingegen wird die Richtung einer Futterquelle lediglich bis $30 \mathrm{~m}$ angegeben (Abb. 2b), die Entfernungen jedoch bis zu 40 m (Abb. 3b). Der Zeitverlauf der Sammelaktivität zeigt bei beiden Arten zwei Phasen. In der ersten Phase verlassen von Sammlerinnen alarmierte Bienen den Stock ohne Information über den Ort der Futterquelle. In der darauffolgenden Phase jedoch verfügen die Sammelbienen über die entsprechende Information: nach 35 Minuten (M. scutellaris) bzw. 85 Minuten (M. quadrifasciata) fliegen signifikant mehr Bienen zur Futterquelle als zur Kontrollfutterquelle (Abb. 4). Unsere Befunde sprechen für die folgende Sequenz der Ereignisse: (i) findet eine Sammelbiene eine lohnende Futterquelle, übermittelt sie im Stock Information über den Duft und die Qualität des Futters. (ii) Alarmierte Stockgenossinnen suchen daraufhin ungerichtet nach einer entsprechenden Futterquelle. In tropischen Wäldern könnte diese Strategie ausreichen, um Massenblüher erfolgreich auszubeuten. (iii) Bienen, die während dieser Zufalls-Suche erfolglos blieben, kehren in den Stock zurück und erhalten von erfolgreichen Sammelbienen Information über den Futterstandort.

Die Verhaltensunterschiede zwischen M. scutellaris und M. quadrifasciata erklären sich möglicherweise aus Unterschieden ihrer natürlichen Lebensräume: $M$. quadrifasciata lebt in der dichten Vegetation des Brasilianischen Atlantischen Regenwaldes, $M$. scutellaris hingegen in weit offeneren Wäldern.
Massenblüher sind im dichten Regenwald häufiger anzutreffen als in offenem Waldgelände. Eine Suchstrategie, die mehr oder weniger auf Zufall beruht, könnte somit gerade für M. quadrifasciata ausreichen.

stachellose Bienen / Sammelverhalten / Rekrutierung / Richtungskommunikation und Entfernungskommunikation / Melipona

\section{REFERENCES}

[1] Bruijn L.L.M. de, Sommeijer M.J., Colony foraging in different species of stingless bees (Apidae, Meliponinae) and the regulation of individual nectar foraging, Insectes Soc. 44 (1997) 35-47.

[2] Esch H., Die Bedeutung der Lauterzeugung für die Verständigung der stachellosen Bienen, Z. Vergl. Physiol. 56 (1967) 199-220.

[3] Esch H., Esch I., Kerr W.E., Sound: An element common to communication of stingless bees and to dances of the honeybee, Science 149 (1965) 320-321.

[4] Frisch K. von, Tanzsprache und Orientierung der Bienen, Springer Verlag, Berlin, 1965.

[5] Hrncir M., Jarau S., Zucchi R., Barth F.G., Recruitment behavior in stingless bees, Melipona scutellaris and M. quadrifasciata. II. Possible mechanisms of communication, Apidologie 31 (2000) 93-113.

[6] Kerr W.E., Some aspects of the evolution of social bees (Apidae), Evol. Biol. 3 (1969) 119-175.

[7] Kerr W.E., Communication among Melipona workers (Hymenoptera: Apidae), J. Insect. Behav. 7 (1994) 123-128.

[8] Kerr W.E., Biologia e manejo da tiúba: A abelha do Maranhão, EDUFMA, Universidade Federal do Maranhão, São Luís, MA, Brasil, 1996.

[9] Kerr W.E., Ferreira A., Simões de Mattos N., Communication among stingless bees - additional data (Hymenoptera: Apidae), J. N. Y. Entomol. Soc. 71 (1963) 80-90.

[10] Lindauer M., Über die Verständigung bei indischen Bienen, Z. Vergl. Physiol. 38 (1956) 521-557.

[11] Lindauer M., Kerr W.E., Die gegenseitige Verständigung bei den stachellosen Bienen, Z. Vergl. Physiol. 41 (1958) 405-434.

[12] Michener C.D., The social behavior of the bees: a comparative study, Belknap Press of Harvard University Press, Cambridge, Massachusetts, 1974. 
[13] Nieh J.C., The role of a scent beacon in the communication of food location by the stingless bee, Melipona panamica, Behav. Ecol. Sociobiol. 43 (1998) 47-58.

[14] Nieh J.C., Roubik D.W., A stingless bee (Melipona panamica) indicates food location without using a scent trail, Behav. Ecol. Sociobiol. 37 (1995) 63-70.

[15] Roubik D.W., Ecology and natural history of tropical bees, Cambridge University Press, Cambridge, Massachusetts, 1989.

[16] Roubik D.W., Aluja M., Flight ranges of Melipona and Trigona in tropical forest, J. Kans. Entomol. Soc. 56 (1983) 217-222.
[17] Roubik D.W., Buchmann S.L., Nectar selection by Melipona and Apis mellifera (Hymenoptera: Apidae) and the ecology of nectar intake by bee colonies in a tropical forest, Oecologia (Berlin) 61 (1984) 1-10.

[18] Wilms W., The highly eusocial bees of Boracéia: Community structure, resource partitioning, and their role as pollinators, in: Anais do II Encontro Sobre Abelhas, Ribeirão Preto - SP, Brazil, 1996, pp. 196-204.

[19] Wilms W., Imperatriz-Fonseca V., Engels W., Resource partitioning between highly eusocial bees and possible impact of the introduced africanized honeybee on native stingless bees in the Brazilian Atlantic Rainforest, Stud. Neotrop. Fauna \& Environ. 31 (1996) 137-151. 
S. Jarau et al. 